\title{
Family farming in times of Covid-19
}

\section{Agricultura familiar em tempos de Covid-19}

\author{
Suzi Barletto CAVALLI1 ID 0000-0002-2835-9424 \\ Panmela SOARES1 ID 0000-0002-2449-6886 \\ Suellen Secchi MARTINELLI ${ }^{1}$ ID 0000-0001-9263-0867 \\ Sergio SCHNEIDER ${ }^{2}$ iD 0000-0002-4353-6732
}

\section{A B S T R A C T}

Family farming plays a vital role in the global food supply. The mobility restriction measures adopted internationally to contain Covid-19 are necessary to control the pandemic progress. However, they can impair food production and distribution. This paper aims to discuss the effects of the Covid-19 containment measures on the production and distribution of family farming food, and strategies to strengthen this sector. Sanitary and social distancing requirements, the interruption of supply to institutional markets, the closure of local farmers' markets, or people's declining food demand are hampering family farming food production's flow and shrinking family farmers' income. This situation can jeopardize the food sovereignty and nutritional security of the population in the medium and long term. Access to Personal Protective Equipment, the reorganization of local farmers' markets, investment in new technologies for direct commercialization, guarantee of minimum income, and the strengthening/expansion of institutional food purchases are some of the strategies that can contribute to overcome the new challenges imposed on family farming as a result of the Covid-19 pandemic. We conclude the article by arguing that the support to and enhancement of the family farming sector are strategic to ensure food supply and to strengthen food and nutrition sovereignty and security.

Keywords: Coronavirus infections. Farmers. Food supply. Sustainable farming.

\section{R E S U M O}

A agricultura familiar desempenha um importante papel no abastecimento alimentar mundial. As medidas de restrição de mobilidade adotadas internacionalmente visando a contenção da Covid-19 são necessárias para

1 Universidade Federal de Santa Catarina, Centro de Ciências da Saúde, Programa de Pós-Graduação em Nutrição. R. Delfino Conti, s/n., Trindade, 88040-900, Florianópolis, SC, Brasil. Correspondence to: P. SOARES. E-mail: $<$ panmela.soares@gmail.com>.

2 Universidade Federal do Rio Grande do Sul, Departamento de Sociologia, Programas de Pós-Graduacão em Desenvolvimento Rural e Sociologia, Porto Alegre, RS, Brasil.

How to cite this article

Cavalli SB, Soares P, Martinelli SS, Schneider S. Family farming in times of Covid-19. Rev Nutr. 2020;33:e200180. https:// doi.org/10.1590/1678-9865202033e200180 
controlar o avanço da pandemia; no entanto, podem ter um efeito negativo na produção e na distribuição de alimentos. O objetivo deste artigo é discutir as implicações das medidas de contenção da Covid-19 na produção e distribuição de alimentos da agricultura familiar e possiveis estratégias para fortalecer esse setor. As exigências sanitárias e de distanciamento social, a interrupção no fornecimento a mercados institucionais e o fechamento de feiras livres elou diminuição na demanda por parte da população estão dificultando o escoamento da produção de alimentos da agricultura familiar e diminuindo a renda dos(as) agricultores(as). Essa situação pode, a médio e longo prazo, ter um efeito negativo na soberania e segurança alimentar e nutricional da população. O acesso a equipamentos de proteção individual, a reorganização de feiras livres, o investimento em novas tecnologias para a comercialização direta, a garantia de renda mínima e o fortalecimento/ampliação da compra institucional de alimentos são algumas das estratégias que podem contribuir para a superação dos desafios impostos à agricultura familiar em consequência da Covid-19. Apoiar e desenvolver esse setor são medidas estratégicas que devem ser adotadas para garantir a oferta de alimentos para a população e fortalecer a soberania e segurança alimentar e nutricional.

Palavras-chave: Infecções por coronavirus. Agricultores. Abastecimento de alimentos. Agricultura sustentável.

\section{NTRODUCTION}

Family farmers are responsible for the majority of the productive units that exist in the rural areas of the planet and contribute with an important part of food production [1]. The relevance of family farming to food systems became clearer in 2014, when the United Nations set the International Year of Family Farming, which triggered an important debate in society and governments $[2,3]$. Since then, it became evident the central role of this group in the food and nutritional sovereignty and security, poverty eradication, protection of the environment, and the strengthening of a sustainable development $[1,2,4-6]$. Family farming is estimated to account for $80 \%$ of the world food production, occupying $75 \%$ of agricultural land [7]. These data suggest the relevance of family farming for the food supply in the world.

Within the scope of Brazilian public policies, a family farmer is defined as a farmer who practices activities in rural areas on small portions of land and predominantly uses family members' labor. Traditional peoples and communities, land reform settlers, foresters, aquaculturists, extractivists, and fishermen can also be considered family farmers [8]. This productive segment has a leading role in the Brazilian agrarian structure, as it is the main social category, accounting for $77 \%$ of the total farmers units according to the Agricultural Census conducted in 2017, which means an absolute number of 3,897,408 units. The majority of people working in agriculture in Brazil are family farmers, since small holder farms generate 10.1 million jobs, which represents $67 \%$ of the total economically active population employed in agricultural establishments [9].

Among the main sales channels used by family farmers to sell their production are street markets and public purchases - especially the National School Feeding Program [10,11]. Fresh foods are the most produced and commercialized foods by family farmers, particularly vegetables and fruits [10]. Research showed that the integration of family farming in the institutional market via public purchases has a positive impact on the quality of the food offered, given the increase in the quantity and variety of fresh food offered as well as the inclusion of products from regional biodiversity $[12,13]$.

The reality of Brazilian family farming reflects the characteristics already demonstrated by studies carried out in other international contexts, which indicated that in the regions where family farming predominates, food culture and inheritances related to existing culinary knowledge are much more varied. In regions where large farms predominate producing staple food (soy, corn, wheat and others), the food habits are based on products purchased in supermarkets, because farmers have 
already stopped growing the crops they used for their own nutrition [14]. Small rural properties help to maintain the diversity of agricultural products and nutrients worldwide [15].

The importance of strengthening family farming lies not only in the role this segment plays in urban population's food supply, but also in its potential for income distribution and rural population's poverty and social vulnerability reduction $[1,7]$. It is estimated that a large part of the population facing food insecurity lives in rural areas $[16,17]$.

The measures adopted to curb the advancement of Covid-19, such as the closure of borders and of local farmers' markets, as well as the cessation of public purchases, highlight the weaknesses of the food system and may have a negative impact on production and marketing of food produced by family farms, increasing social vulnerability and food insecurity[18-20]. On the other hand, the exposure of these weaknesses can represent an opportunity to drive changes in the form of production and commercialization of food, towards socially fair and environmentally more sustainable forms, such as small-scale production, using organic production and short food supply chains $[19,21]$. Short supply chains suffer less from displacement restrictions and their strengthening can increase job opportunities and improve the quality of life for people in a region, besides being potential alternatives to guarantee food supplies during the current crisis [18].

The purpose of this article is to discuss the implications of covid-19 containment measures on the production and distribution of family farming food and strategies for the strengthening of this sector.

\section{DE VE L OPM E N T}

The scientific and technological advances of the last decades, together with the opening of markets, drove important changes in the way society is organized around food production. In an increasingly globalized market, there is a growth in food production and processing at a global level, a strengthening of large international corporations in the agri-food sector (production, processing and distribution), and a greater dependence on the international market [22,23].

The mobility restriction measures adopted at international level to contain Covid-19, necessary to control the advance of the pandemic, highlighted the fragility of the current food system and revived the debate about the stability of the internal food supply and food security [24-27]. This context highlights the fact that the political model based on the concept of food security and the free market may not be adequate to ensure the availability and access of food by the population. Also, it may represent a window of opportunity to incorporate the sovereignty perspective into food policy.

The concept of Food Sovereignty advocated by Via Campesina highlights the autonomy of peoples in deciding their own food and production system, emphasizing the role of producers and consumers in the decision-making of food policies, above market demands $[28,29]$. Thus, family farming represents a strategic sector for the construction of food sovereignty [25]. However, thinking of food sovereignty as a determinant of the food system, especially in the post-pandemic, brings to light the need for reorganization of farmers [30]. This is because many small-scale producers suffer the constraints and restrictions that are expressed in the lack of priority and recognition by national public policies, as well as in the weakness of access to their main assets, such as land, water, inputs and storage and processing infrastructures [31].

As part of Brazil's public policies, a series of state strategies have been developed in recent decades aimed at protecting and strengthening family farming [1,32]. Among these strategies, the 
public purchases of food produced by family farming stand out $[1,13,32,33]$. Studies have shown the benefits of buying food from family farmers for both consumers and producers [13,34-36] and enhance the importance of strengthening this productive sector. However, several of these strategies may be threatened by the discontinuity of public policies and the negative consequences of Covid-19 control measures (such as the closure of institutional markets and street markets).

Specifically, the decrease in the demand for food caused by the closing of institutional markets, farmers' markets, hotels, as well as price deregulation is changing food production and commercialization by the Brazilian family farmers $[37,38]$. In order to guarantee food production for the entire population and not to increase the situation of economic vulnerability of the farmers' families, it is necessary to adopt measures with a clear and emergency objective in mind to stimulate the production and the income assurance for family farmers. Initiatives such as food baskets delivered at home and diffusion strategies through social networks have been used by farmers' organizations as an alternative for the production outflow [37]. In this type of initiative, family farming, especially that with an agroecological basis, forms an alternative network of short production and sales circuits and becomes strengthened when it forms associative partnerships and is fostered by public policies [39].

On the other hand, state governments and rural workers' organizations are developing strategies to guarantee financial and productive security. Less frequently, actions to guarantee income to farmers and to regulate the food system and agricultural prices are also being developed [40].

Chart 1 groups strategies that can be adopted to minimize the negative impact on food production and commercialization and on the income of family farmers resulting from actions to control the pandemic.

Chart 1. Strategies to minimize the negative implications in food production and marketing, arising from actions to combat Covid-19.

Factors arising from COVID-19

production and marketing.
Problems

Difficulty in ensuring materialization of the Municipal agricultural departments can provide recommendations of hygiene and social guidance materials, alcohol gel, masks (when distance in the production and marketing of needed). food.

Technical assistance agencies can conduct (remote) training with family farmers to guide safe ways of production and marketing.

Supply departments can establish systems for controlling the number of people at street markets and make the necessary personal protective equipment available to market traders and consumers.

Closing of establishments (street markets, hotels, institutional restaurants, commercial restaurants).
Difficulties in delivering production

Consumers increased the demand for supermarkets, online shopping and home delivery.
Support the development of technological tools to assist online sales.

Reorganization of the street market (number of days/ frequency/ number of vendors/ times/ entrance control/ use of masks, and other needs).

Create and disseminate guidance manuals of good purchasing practices for merchants and consumers. Inclusion of food from family farming in basic food baskets distributed by governmental and nongovernmental organizations.

Creation of online platforms that assist direct purchase and virtual street markets.

Creation of specific supply centers for local food produced by family farming. 
Chart 1. Strategies to minimize the negative implications in food production and marketing, arising from actions to combat Covid-19.

\begin{tabular}{|c|c|c|}
\hline Factors arising from COVID-19 & Problems & Alternatives \\
\hline $\begin{array}{l}\text { Closing of institutional } \\
\text { markets. }\end{array}$ & Difficulties to deliver production. & $\begin{array}{l}\text { Guarantee and expand the purchase of food } \\
\text { provided for school meals National School Food } \\
\text { Program (PNAE) and distribute baskets to students } \\
\text { in socially vulnerable situations. } \\
\text { Guarantee and expand the purchase of food via } \\
\text { Institutional Purchase to supply public Food and } \\
\text { Nutrition Equipment, such as popular restaurants, } \\
\text { community kitchens and food banks. } \\
\text { Expansion of purchase notices via the Food } \\
\text { Acquisition Program (PAA) for donation to institutions } \\
\text { that serve populations in situations of food } \\
\text { insecurity. }\end{array}$ \\
\hline Decreased sales & Decreased income & $\begin{array}{l}\text { Guarantee of emergency basic income for family } \\
\text { farmers. } \\
\text { Rural credit. } \\
\text { Technical assistance and rural extension. }\end{array}$ \\
\hline
\end{tabular}

Note: Chart elaborated by the autors based on [37-40, 42].

PAA: Programa de Aquisição de Alimentos; PNAE: Programa Nacional de Alimentação Escolar.

To implement these strategies, it is necessary to develop joint actions between civil society and public authorities. It is necessary for social movements to improve their capacity to charge the government. These relations should also be strengthened in order to meet the needs of the population, especially in these pandemic times $[30,41]$. In this connection, family farming organizations have demanded emergency protection measures. An example is Bill 735/2020, approved by the National Congress in August 2020 [42]. The strategies presented in the project include the maintenance of public purchases of food produced by family farmers, assistance through the Environmental Conservation Support Program, supply guarantee of essential services such as water, electricity and gas for the beneficiaries of the Bolsa Família welfare program, suspension of debt collection by financial institutions in addition to more specific physical goals and programmatic actions.

\section{CONCLUSION}

In view of its numerical relevance and due to its role in generating jobs and income, family farming plays a strategic role not only for food production, but also for building lasting solutions for the improvement of living conditions in rural areas and for the quality of the food supply. The Covid-19 containment measures are having a negative effect on production and sales of food originating from this productive segment. To minimize these negative effects, it is essential that policy makers as well as governments and civil society in general, be shown that investment in this social group is worthwhile and justified, both because of the legitimacy represented by its vast numerical majority, and because of the potential it represents to guarantee supply, sovereignty and nutritional security.

\section{CONTRIBUTORS}

All authors collaborated in the writing of the manuscript and approved the final version. 


\section{REFERE N CES}

1. Graeub BE, Chappell MJ, Wittman H, Ledermann S, Kerr RB, Gemmill-Herren B. The state of family farms in the world. World Dev. 2016;87:1-15. https://doi.org/10.1016/j.worlddev.2015.05.012

2. Food and Agriculture Organization of the United Nations. United Nations decade of family farming 2019-2028: global action plan. Rome: Organization; 2019 [cited 2020 May 10]. Available from: http://www.fao.org/3/ ca4672en/ca4672en.pdf

3. Grisa C, Sabourin E, Le Coq J-F. Políticas públicas para a agricultura familiar na América Latina e Caribe. Raízes. 2018;38:7-21. https://doi.org/10.37370/raizes.2018.v38.35

4. Palmioli L, Grando S, Di lacovo F, Fastelli L, Galli F, Prosperi P, et al. Small farms' strategies between selfprovision and socio-economic integration: effects on food system capacity to provide food and nutrition security. Local Environ. 2020;25:43-56. https://doi.org/10.1080/13549839.2019.1697869

5. Fondo Internacional de Desarrollo Agrícola. La agricultura familiar en América Latina: un nuevo análisis comparativo. Roma: Fondo; 2014 [citado 10 jun 2020]. Disponible en: https://www.ifad.org/documents/38 714170/39135645/Family+farming+in+Latin+America+-+A+new+comparative+analysis_s.pdf/9330a6c4c897-4e1c-9c05-1144ebec0457

6. United Nations Environment Programme. Agriculture: investing in natural capital. Rome: Programme; 2011.

7. Food and Agriculture Organization of the United Nations. The state of food and agriculture innovation in family farming. Rome: Organization; 2014. Available from: http://www.fao.org/3/a-i4040e.pdf

8. Brasil. Lei no 11.326, de 24 de julho de 2006. Estabelece as diretrizes para a formulação da Política Nacional da Agricultura Familiar e Empreendimentos Familiares Rurais. Braślia: Diário Oficial da União; 2006.

9. Instituto Brasileiro de Geografia e Estatística (Brasil). Censo agropecuário 2017:resultados definitivos IBGE. Rio de Janeiro: Instituto; 2017 [citado 20 Mar 20]. Disponível em: https://sidra.ibge.gov.br/pesquisa/censoagropecuario/censo-agropecuario-2017.

10. Cavalli SB, Soares P, Martinelli SS, Fabri RK. Oferta de alimentos saudáveis em instituiç̧ões públicas: instrumentalização de responsáveis técnicos dos serviços de alimentação e agricultores/as familiares para aquisição sustentável de alimentos. Relatório técnico de pesquisa chamada CNPq/MCTIC n. 016/2016 processo: 442830/2016-5. Florianópolis: Universidade Federal de Santa Catarina; 2020.

11. Bocchi CP, Magalhães ÉS, Rahal L, Gentil P, Gonçalves RS. The nutrition decade, the public policy for food security, and public purchases from family farming in Brazil: el decenio de las Naciones Unidas de Acción sobre la nutrición, la política de seguridad alimentaria y nutricional, y las compras públicas de la agricultura familiar en Brasil. Rev Panam Salud Publica. 2019;43:e84-e. https://doi.org/10.26633/RPSP.2019.84

12. Fabri RK, Proença RPC, Martinelli SS, Cavalli SB. Regional foods in Brazilian school meals. Briti Food J. 2015;117:1706-19. https://doi.org/10.1108/BFJ-07-2014-0275

13. Soares P, Davó-Blanes MC, Martinelli SS, Melgarejo L, Cavalli SB. The effect of new purchase criteria on food procurement for the Brazilian school feeding program. Appetite. 2017;108:288-94. https://doi.org/10. 1016/j.appet.2016.10.016

14. Fanzo J. Does global goal setting matter for nutrition and health? Ama J Ethics. 2018;20:E979-86. https:// doi.org/10.1001/amajethics.2018.979

15. Herrero M, Thornton PK, Power B, Bogard JR, Remans R, Fritz S, et al. Farming and the geography of nutrient production for human use: a transdisciplinary analysis. Lancet Planet Health. 2017;1:e33-e42. https://doi. org/10.1016/S2542-5196(17)30007-4

16. Fanzo J. From big to small: the significance of smallholder farms in the global food system. Lancet Planet Health. 2017;1. https://doi.org/10.1016/S2542-5196(17)30011-6

17. Fondo Internacional de Desarrollo Agrícola. Panorama de la pobreza rural en América Latina y el Caribe Santiago: Fondo; 2018 [citado 10 May 2020]. Disponible en: http://www.fao.org/3/CA2275ES/ca2275es.pdf

18. Cappelli A, Cini E. Will the COVID-19 pandemic make us reconsider the relevance of short food supply chains and local productions? Trends Food Sci Tech. 2020;99:566-7. https://doi.org/10.1016/j.tifs.2020.03.041

19. Preiss PV. Challenges facing the COVID-19 pandemic in Brazil: lessons from short food supply systems. Agr Hum Values. 2020;37:571-2. https://doi.org/10.1007/s10460-020-10062-4 
20. Aquino EML, Silveira IH, Pescarini JM, Aquino R, Souza-Filho JA, Rocha AS, et al. Social distancing measures to control the COVID-19 pandemic: potential impacts and challenges in Brazil. Ciênc Saude Colet. 2020;25:2423-46. https://doi.org/10.1590/1413-81232020256.1.10502020

21. O'Brien D. A small lowa farmer's perspective on COVID-19. Agr Hum Values. 2020:1-2. https://doi. org/10.1007/s10460-020-10084-y

22. Stuckler D, Nestle M. Big food, food systems, and global health. Plos Med. 2012;9:e1001242. https://doi. org/10.1371/journal.pmed.1001242

23. Rayner G, Hawkes C, Lang T, Bello W. Trade liberalization and the diet transition: a public health response. Health Promot Int. 2006;21:67-74. https://doi.org/10.1093/heapro/dal053

24. Altieri MA, Nicholls Cl. Agroecology and the emergence of a post COVID-19 agriculture. Agr Hum Values. 2020;37:525-6. https://doi.org/10.1007/s10460-020-10043-7

25. Sauer S. Interview with João Pedro Stédile, national leader of the MST Brazil. J Peasant Stud. 2020:1-17. https://doi.org/10.1080/03066150.2020.1782892

26. Benton TG. COVID-19 and disruptions to food systems. Agric Human Values. 2020:1-2. https://doi. org/10.1007/s10460-020-10081-1

27. Fore HH, Dongyu Q, Beasley DM, Ghebreyesus TA. Child malnutrition and COVID-19: the time to act is now. Lancet. https://doi.org/10.1016/S0140-6736(20)31648-2

28. La Via Campesina. Key Documents (Food Sovereignty) 2020. Zimbabwe: La via Campesina; 2020 [cited 2020 June 25]. Available from: https://viacampesina.org/en/what-are-we-fighting-for/food-sovereignty-and-trade/ key-documents-food-sovereignty/

29. Chappell MJ, Wittman H, Bacon CM, Ferguson BG, Barrios LG, Barrios RG, et al. Food sovereignty: an alternative paradigm for poverty reduction and biodiversity conservation in Latin America. F1000Res. 2013;2:235. https://doi.org/10.12688/f1000research.2-235.v1

30. Van Der Ploeg JD. From biomedical to politico-economic crisis: the food system in times of Covid-19. J Peasant Stud. 2020:1-29. https://doi.org/10.1080/03066150.2020.1794843

31. Fondo Internacional de Desarrollo Agrícola. Agricultura familiar en América Latina y el Caribe: recomendaciones de política Santiago: Fondo; 2014 [cited 2020 July 27]. Available from: http://www.fao.org/3/i3788s/i3788s. pdf

32. Valencia V, Wittman H, Blesh J. Structuring markets for resilient farming systems. Agron Sustain Dev. 2019;39. https://doi.org/10.1007/s13593-019-0572-4

33. Schabarum JC, Triches RM. Aquisição de produtos da agricultura familiar em municípios paranaenses: análise dos produtos comercializados e dos preços praticados. Rev Econ Sociol Rural. 2019;57:49-62.

34. Schneider $S$, Thies VF, Grisa C, Belik W. Potential of public purchases as markets for family farming: an analysis of Brazilian school feeding program between 2011 and 2014. In: Barling D, editor. advances in food security and sustainability: Elsevier; 2016.

35. Soares P, Martinelli SS, Melgarejo L, Cavalli SB, Davó-Blanes MC. Using local family farm products for school feeding programmes: effect on school menus. Brit Food J. 2017;119:1289-300. https://doi.org/10.1108/BFJ08-2016-0377

36. Martinelli SS, Soares P, Fabri RK, Campanella GRA, Rover OJ, Cavalli SB. Potencialidades da compra institucional na promoção de sistemas agroalimentares locais e sustentáveis: o caso de um restaurante universitário. Segurança Alimentar e Nutricional. 2015;22:558-73.

37. Cavalli SB, Martinelli SS, Soares P. Relatório de resultados da consulta a entidades vinculadas à agricultura familiar sobre as questões relacionadas à produção e comercialização de alimentos frente a pandemia do coronavírus (COVID-19). Florianópolis: Rede Sustenta; 2020.

38. Preiss PV, Navarro RS, Silva GPD, Weber J, Vogt HDM, Faccin C, et al. Relatório de resultados preliminares da pesquisa "o impacto da covid-19 na comercialização direta da agricultura familiar no RS": Regiões Metropolitana do Delta do Jacuí e Vale do Rio Pardo. Santa Cruz do Sul: OBSERVA-DR, 2020.

39. Darolt MR, Lamine C, Brandenburg A, Alencar MDCF, Abreu LS. Redes alimentares alternativas e novas relações produção-consumo na França e no Brasil. Ambient Soc. 2016;19:1-22. https://doi.org/http://dx.doi. org/10.1590/1809-4422ASOC121132V1922016 
40. Valadares AA, Alves F, Galiza M, Silva SP. Agricultura familiar e abastecimento alimentar no contexto do COVID-19: uma abordagem das ações públicas emergenciais Brasília: Instituto de Pesquisa Econômica Aplicada; 2020 [citado 12 Jun 2020]. Disponível em: https://www.ipea.gov.br/portal/images/stories/PDFs/ nota_tecnica/200508_nt_disoc_n_69_web.pdf.

41. Patel R, Goodman J. The long new deal. J Peasant Stud. 2020;47:431-63. https://doi.org/10.1080/0306615 0.2020 .1741551

42. Brasil. Projeto de Lei $n^{\circ} 735$. Dispõe sobre medidas emergenciais de amparo aos agricultores familiares do Brasil para mitigar os impactos socioeconômicos da Covid-19; altera as Leis nºs 13.340, de 28 de setembro de 2016, e 13.606, de 9 de janeiro de 2018; e dá outras providências (Lei Assis Carvalho). Brasília: Presidência da República; 2020. 